\title{
Article \\ Barriers and Drivers of Transition to Sustainable Public Transport in the Philippines
}

\author{
Charmaine Samala Guno ${ }^{1}$, Angelie Azcuna Collera ${ }^{2}$ and Casper Boongaling Agaton ${ }^{3,4, *(D)}$ \\ 1 Mindoro State College of Agriculture and Technology, Masipit, Calapan City, Oriental Mindoro 5200, \\ Philippines; csguno@minscat.edu.ph \\ 2 Center for Human Development, University of Science and Technology of Southern Philippines-Cagayan de \\ Oro Campus, Misamis Oriental 9000, Philippines; acollera@ustp.edu.ph \\ 3 Copernicus Institute of Sustainable Development, Utrecht University, Princetonlaan 8a, \\ 3584 CB Utrecht, The Netherlands \\ 4 Utrecht School of Economics, Utrecht University, Kriekenpitplein 21-22, 3584 EC Utrecht, The Netherlands \\ * Correspondence: c.b.agaton@uu.nl
}

Citation: Guno, C.S.; Collera, A.A.; Agaton, C.B. Barriers and Drivers of Transition to Sustainable Public Transport in the Philippines. World Electr. Veh. J. 2021, 12, 46. https:// doi.org/10.3390/wevj12010046

Academic Editor: Aritra Ghosh

Received: 27 February 2021

Accepted: 17 March 2021

Published: 19 March 2021

Publisher's Note: MDPI stays neutral with regard to jurisdictional claims in published maps and institutional affiliations.

Copyright: (C) 2021 by the authors. Licensee MDPI, Basel, Switzerland. This article is an open access article distributed under the terms and conditions of the Creative Commons Attribution (CC BY) license (https:// creativecommons.org/licenses/by/ $4.0 /)$

\begin{abstract}
Electrification of public utility vehicles plays a vital role in the transition towards a more sustainable transport system. However, the adoption of electric vehicles (EVs) encounters varying challenges ranging from financing issues, government policies, and public acceptance. Using the Philippines as a case, this research applies political, economic, social, technological, legal, and environmental (PESTLE) analysis to determine how different drivers affect the adoption of EVs in the public transport system from various transport stakeholders' vantage points. Survey results identified economic and technological factors as the main barriers to the adoption of electric public transport. This includes high investment and operational costs, lack of charging infrastructure, issues in driving range and use in different terrains, and the availability of EV parts and repair stations. On the other hand, the main enabler is the significant public support for the modernization of the public transport system through EVs, backed up by policy and legal drivers. For a zero-emission public transport system, this study recommends that the government should invest in sustainable sources of energy, develop more public infrastructure, diversify the transport sector, fund the development of locally made EVs, and initiate a massive information campaign in educating the public of its advantages.
\end{abstract}

Keywords: electric vehicles; PESTLE; public utility vehicle; sustainable transportation; participatory development; good governance

\section{Introduction}

In this energy transition era towards a net-zero carbon economy, electrification of the public transport system has been rapidly spreading across countries and various types of vehicles, from rail to buses and cars. As aviation, marine transportation, and heavy-duty road vehicles are the most difficult modes to decarbonize, the electrification of passenger cars and public utility vehicles (PUVs) appears to have the potential to decrease greenhouse gas (GHG) emissions and other pollutants. In 2019 alone, electric cars topped 2.1 million, which accounted for $2.6 \%$ of global car sales and registered a $40 \%$ year-onyear increase [1]. Electric vehicles (EVs) are significantly expanding with the accelerated technological developments in the electrification of two/three-wheelers, buses, and trucks while the market for them grows [1]. With the displacement of combustion vehicles, EVs are expected to lessen air pollution, decrease the dependence on oil, and enable the transition towards a zero-emission transport sector. Developed countries put considerable efforts into making electric mobility more attractive by giving incentives such as tax exemption, one-off registration tax, rebates on the upfront cost of EV, energy bills, and parking fees, purchase subsidy, and developing public charging stations [2-5]. Developing countries, on 
the other hand, give limited incentives like purchase subsidy, tax discount or excise duty, discount on the technical-mechanical review and in the compulsory insurance, preferential parking, and expansion in the infrastructure of charging points [6-8].

In the Philippines, transportation is a key sector that links population and economic centers across the islands consisting of road, rail, maritime, and aviation. While aviation and maritime transport play a crucial role in inter-island mobility, the most popular and dominant mode of travel is road transport [9]. Among the PUVs in the country, the jeepneya refurbished American jeep-is the most popular, with around 270,000 franchised units on the road across the country, followed by the tricycle - a traditional three-wheeled rickshaw or "tuk-tuk" - with 1.6 million units registered as motorcycles and tricycles [6]. While jeepneys and tricycles are owned by private operators, they are classified as PUVs in the case country as they are available for use by the general public, charge set fares for every trip, and operate on specific routes. Other modes of road public transport include buses, all-utility vehicles, taxis, and "pedicabs"-non-motorized rickshaws [10]. With the rapid growth in economic activities and urbanization, the PUVs, along with private vehicles, exponentially increased in numbers, which resulted in poorer air quality and frequent traffic congestion in the cities [6]. To address these problems, the government of the Philippines implemented several policies such as Clean Air that aims to maintain clean air that meets the National Air Quality guidelines, and the PUV Modernization Program (PUVMP) which replaces the old combustion vehicles (c-PUVs) with more sustainable electric vehicles (e-PUVs) (see Figure 1). The program features ten components which include regulatory reform, route planning, route rationalization, fleet modernization, industry consolidation, financing, pilot implementation, stakeholder support mechanism, and communication [11]. It aims to employ around 100,000 electric tricycles (e-trikes) annually and 200,000 electric jeepneys (e-jeepneys) or EURO-4 jeepneys in the next six years, giving "5, 6, 7, 8" incentives, including $5 \%$ subsidy for each unit of e-PUV, $6 \%$ interest rate for purchase loan payable in 7 years, and an equity subsidy of PHP 80 thousand ( USD \$1500) [10]. Despite these benefits, transport stakeholders are still hesitant to adopt e-PUVs due to high investment costs, lack of technical and policy support, skepticism on strict implementation of the programs, and public acceptance. This research aims to investigate the barriers and drivers of the adoption of e-PUV from a multidisciplinary point of view of various transport stakeholders through the lens of political, economic, social, technological, legal, and environmental (PESTLE) analysis - an adherence to participatory governance as articulated in the United Nations Sustainable Development Goals (UN SDGs).

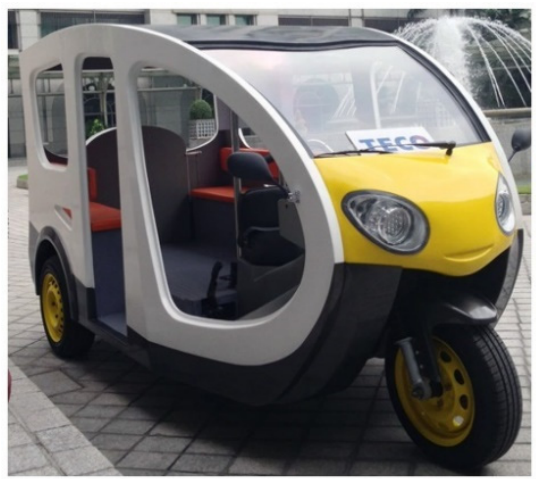

(a)

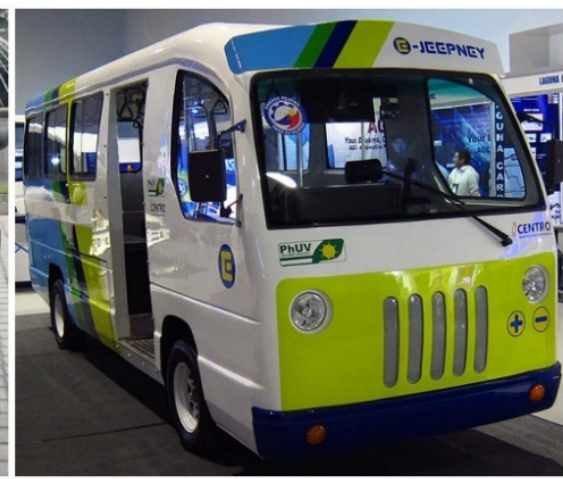

(b)

Figure 1. Modernized public utility vehicles (PUVs) in the Philippines: (a) e-trike and (b) e-jeepney. Source: Top Gear Philippines.

Previous studies used various methods to identify and evaluate the barriers (and drivers) to the adoption of EV. In one study, Andelacio et al. [12] applied a mixed-method approach to determine the perceptions of three stakeholders in jeepney operations (operators/drivers, passengers, and manufacturers) on the implementation, challenges, and 
repercussions of the modernization of jeepneys in the Philippines. In another study, de Rubens et al. [13] surveyed 227 transportation and electricity experts across Europe to investigate the challenges for EVs focusing on current and future market implications. Their findings showed that EVs are less favored with current market conditions led by petrol and diesel car industries. They also found that mass adoption of EVs would change the traditional automotive selling chain, directly affecting dealership, maintenance revenue streams, and refueling/recharging structures [13]. Meanwhile, Berkeley et al. [14] applied a multi-level perspective to investigate the drivers of and barriers to socio-technical transitions in the automotive sector. They identified energy, environmental, and economic policies as the main drivers, and socio-technical, economic uncertainty, and consumer awareness/attitude as barriers for EV adoption in Europe. Berkeley, Jarvis, and Jones [15] extended this study by first identifying a multitude of obstacles to EV adoption from European and North American literature, surveying 26,000 motorists in the United Kingdom, and using multivariate regression analysis to test whether the conceptualized barriers were mitigated or aggravated by various respondents' characteristics. The findings classified the resistance to EV adoption as economic uncertainty and socio-technical factors and concluded that EV adoption is complex and multi-faceted and should be tackled in a more holistic approach.

One of the holistic approaches is multicriteria decision-making (MCDM) or multicriteria decision analysis (MCDA), which is applied from both a conceptual and a practical perspective. This method is suitable for public transport decision-making as it involves multiple perspectives of analysis (public and private sectors) in the design and operation of the transport system, addressing multiple economic, environmental, and socio-political issues $[16,17]$. Another approach is the SWOT analysis derived from its initials: Strength, Weakness, Opportunities, and Threats. This analysis is well-structured strategic planning to assess the current status of the business in the market by identifying its internal factors (strength and weakness) as well as external factors (opportunities and threats) [18]. With particular regard to passenger EVs, various studies applied SWOT to explore and evaluate the current state and EV market potential as well as to propose some future actions toward sustainable development in the transportation sector [19-21].

The PESTLE analysis, derived from Political, Economic, Social, Technological, Legal, and Environmental factors that affect business planning, is another approach used by organizations to evaluate the impact of the external environment on a business or other form of the entity [22]. A growing number of studies applied this method to analyze the different external factors that enable and hinder the adoption of EVs [23-26]. Combining PESTLE with SWOT is also useful to evaluate the pros and cons of major decisions resulting in a better understanding, acceptance, and successful implementation of projects [27]. To take advantage of SWOT and PESTLE, several studies combined them, like Chodakowska [28], who analyzed the electric vehicle industry and battery management systems whole market research in Finland and Norway based on the current literature. Capuder et al. [29] analyzed the obstacles for large-scale integration and acceptance of EVs, borrowing techniques from integrated risk management, and creating a hybrid method for evaluating the regulatory goals, and Matthews et al. [30] analyzed Tesla's new venture in Tesla batteries that will enable the transition from an electric vehicle company to an energy company that not only supports sustainable energy but also develops innovative technologies to store that energy towards a sustainable energy future. Given its usefulness in business planning, strategic planning, marketing, and product development planning at the organizational level, the main advantages of using PESTLE analysis include costeffectiveness, a deeper understanding of business, alertness to threats, and the method to exploit opportunities [31].

To support the government's PUVMP, this research aims to analyze how external factors affect the adoption of EVs for a sustainable public transport system in the Philippines. Hence, PESTLE analysis is more appropriate to examine and focus on these external factors that transport stakeholders should address in adopting EVs. Besides, different 
stakeholders consider different perspectives-users consider mainly the economic and social perspectives while transport operators, city planners, and policymakers also consider political, legal, technological, and environmental concerns [32]. Specifically, this study aims to answer the questions: (1) what are the political, economic, social, technological, environmental, and legal factors for the adoption of e-PUVs? (2) How do various stakeholders perceive these factors as barriers or drivers for transport modernization? (3) What policies must the government implement to accelerate the transition towards a sustainable public transport system? To address these research questions, we first identify a list of external PESTLE factors from expert interviews. We surveyed different transport stakeholders (drivers, passengers, operators, businesses, and other stakeholders) to evaluate whether the identified factors are barriers or drivers for EV adoption and propose other means that support the PUVMP. Finally, this research intends to give policy recommendations, from the results of the study, in the realization of the government program in modernizing the transport system into a more sustainable and environment-friendly system.

\section{Literature Review}

\subsection{Electrification of Public Transport-Opportunities and Challenges}

Electrification of public transport, in combination with electricity production from renewable energy sources, is an essential part of improving the environmental profile of a public transportation system [33]. This can be carried out by utilizing different technological solutions such as bus trolleys, electric buses, trams, and railways [34-36], as well as localized modes of public transport like electric tuk-tuk [37,38], electric scooters [39], electric rickshaws [10,40], and e-jeepneys [6,41].

The transition towards sustainable transportation provides several benefits including $\mathrm{CO}_{2}$ emission reduction, increase in energy efficiency, improvement of air quality, and the integration of different energy sectors [42]. Large-scale deployment of EVs is expected to reduce $\mathrm{CO}_{2}$ emissions from both transportation and electricity sectors [43]. For instance, a single 18 m city bus consumes about 40,000 L of diesel yearly [33]. Electrification of this bus reduces emissions equivalent to more than 100 tons of $\mathrm{CO}_{2}$ [33]. In the case of localized PUVs in the Philippines, electrification of tricycle and jeepney fleets may reduce emissions by $85 \%$ from 14.98-21.23 $\mathrm{Mt} \mathrm{CO}_{2}$ eq/year to 2.23-3.13 $\mathrm{Mt} \mathrm{CO}_{2}$ eq/year [10]. However, electrification of public transport should be accompanied by the replacement of fossil-fuel power plants, otherwise, this leads to the unfortunate result of increasing emissions instead of achieving a low-carbon transition [44].

In terms of air quality, EVs could significantly reduce air pollutants compared with combustion vehicles. In China, for instance, the transition to EV transport will decrease volatile organic compounds (VOCs), carbon monoxide (CO), nitrous oxides (NOx), particulate matter (PM) 2.5, and PM10 emissions by 56\%, 70\%, 27\%, 24\%, and 17\%, respectively [45]. Shi et al. [45] emphasized that more stringent emission controls, higher EV penetration, and cleaner electricity should be jointly applied to ensure a successful electrification future in China. In the case of the Philippines, electrification of PUVs will decrease PM, NOx, sulfur oxides (Sox), and CO emissions by an average of $96 \%, 82 \%, 59 \%$, and $93 \%$, respectively [10]. Agaton et al. [10] noted that these are relatively higher compared with other studies as the conventional PUVs in the country are less energy-efficient, dilapidated, and smoke-belchers. The study further stressed that significant improvements in air quality can reduce health risks of pollution from public transport, including ischemic heart disease, stroke, lung cancer, chronic obstructive pulmonary disease, and acute lower respiratory infections [10].

Despite the environmental and economic benefits, the electrification of public transport is challenged by various factors. Technological, financial, market, consumer perceptions, and policy challenges deter the shift in the transportation sector [43]. Haddadian et al. [43] proposed a strategic solution to address these challenges through further research and development (R\&D) investments, public-private partnerships, policy intervention, and state-of-the-art business models. In the short-term, the introduction of EVs in public 
transport is still hindered by barriers such as higher cost compared to the combustion vehicles, the lack of capability to guarantee the service in case of delays, the need for proper training for transport company staff, and the time needed to install the charging stations [46]. In the long-term, 100\% electrified public transport would not be a cost-optimal solution due to high investment costs on infrastructure which could not be balanced by the reduced fuel costs [47]. These challenges can be addressed by optimizing the infrastructure through integration of EVs using existing electric public transport infrastructure, innovative energy storage systems that increase operational efficiency, and multi-purpose use of electric public transport infrastructure, via the possibility of supplying energy to other EVs [48].

\subsection{Participatory Development and Good Governance in Transport Planning}

To build the theoretical framework, we draw our insights from participatory development and good governance. In recent decades, the sustainable development debate has moved towards empowerment and a demand-driven approach to governance, implying the participation of stakeholders in the decision-making process at different levels [49]. Different levels may refer to project cycle participation (planning, implementation, monitoring and evaluation, take-over), the type of participation (passive beneficiaries, informants, costsharers, or stakeholders), or to societal levels (local, regional, national) [50]. Participatory development, unlike older development theories that relied on a top-down approach, seeks to engage the local population and increase the level of civic engagement between citizens and their society in development planning [51]. Hence, participatory development does not replace the top-down development approach but attempts to introduce a bottom-up style of development to remedy the government-led approach's limitations by focusing on qualitative improvements in citizens' participation [52]. The process of participatory development leads to numerous outcomes, including the understanding of the key stakeholders in the process and their roles in project planning and implementation, detailed understanding of power, motivations, and resources of each key stakeholder related to the others, and understanding of the key challenges that need to be overcome to move forward on project implementation [53].

Governance is mandatory or voluntary cooperation between a political state and its citizens, the Government and non-governmental organizations, and the public and private institutions [54]. Good governance refers to the process of public administration that maximizes the interest of its citizens. The term "good" in good governance is two-fold: the values of respect for the will of the citizens and promotion of their capabilities to achieve a self-reliant and sustainable development and social justice, and the government's functional aspect of effective, efficient work to achieve these goals [55]. Keping [54] summarized the essential components of good governance which include legitimacy - the quality that social order and authority are voluntarily recognized and obeyed, transparency-the political information available to the public, accountability - fulfill the functions and obligations of the administrators and administrative bodies, rule of law-supreme principle observed by all government officials and citizens, responsiveness-response of administrators to the demands of citizens in a timely and responsible manner, and effectiveness—rational administrative structure at minimized administrative costs.

Participatory development and good governance are related such that the earlier focuses on raising the quality of participation achieving self-reliant and sustainable development and social justice, while the latter provides the government functions needed for the promotion of citizen participation and creation of a conducive environment for the participatory processes [52]. As the participatory process progresses, good governance develops, supporting broader and more inclusive citizen participation, hence, participatory development promotes good governance.

In sustainable transport planning, the participation of the public is often regarded as a formal compulsory phase of the decision-making process as it engages citizens to find the most shared solution in the shortest time to make the process more effective and 
efficient [56]. This participatory approach leads to a better understanding of the design and speeds up the decision-making process and finds out how communication among different stakeholders influences the process of governance [56]. Stakeholders' views and concerns in making transport decisions ensure effective outcomes with well-considered and thoughtful solutions [57].

\subsection{PESTLE Analysis on EV Adoption}

The PESTLE analysis is a tool used as situational analysis for business evaluation purposes and is one of the most frequently applied models in the evaluation of the external business environment that is highly dynamic [58]. Due to its usefulness, a growing number of studies applied this analytical tool in different sustainable technology solutions, including the evaluation of external factors affecting management decisions for coastal zone and freshwater resources $[59,60]$, sustainable buildings [61,62], renewable energies [63,64], biofuels $[65,66]$, and carbon capture and storage $[67,68]$.

In the transport sector, Tan et al. [69] and Sin et al. [70] applied PESTLE to analyze the factors that influence the production of hybrid electric cars. The results from PESTLE analysis showed that all the factors are reasonable to support the move of Toyota to produce hybrid vehicles. Several studies further analyzed the challenges and opportunities for the adoption of electric vehicles. For instance, Månsson [23] developed a PESTLE scenariobased method and analyzed the influence of external factors on energy security, focusing on passenger and freight transport in Sweden. The findings showed that energy use reduction strategies are robust while the perception of demand restrictions is undesirable for some interest groups. With increasing international demand, biofuels perform poorly, while electrification performs best. In another study, Jiang et al. [24] applied PESTLE analysis to compare gasoline and electric cars and used the evaluation as a fundamental base for financial analysis. The study found the environmental advantages of EVs over gasoline cars only if EVs use green electricity, otherwise, EVs will produce greenhouse gases as well. Hernanz et al. [25] applied the PESTLE for the external part of the analysis of the electrification of the whole fleet of public transport in Madrid, Spain. The results supported the proposal of switching to a $100 \%$ electric fleet as the best option in the long term. With the large investments and change costs, a gradual implementation is needed, which includes building new operational centers and charging structures as well as training company employees with this new electrical technology. Further, Sobhani et al. [26] combined PESTLE and Analytic Hierarchy Process-Technique for Order of Preference by Similarity to Ideal Solution (AHP-TOPSIS) based on a qualitative approach with inputs from experts as well as major stakeholders to measure the competitiveness of unconventional modes of transportation in Bangladesh. The study found that economic, social, and political factors had the highest influence on the adoption of unconventional modes of transportation, with rickshaws as the most competitive among them.

\subsection{Literature Gap and Proposed Contribution}

To the best of our knowledge, there has been no study applying PESTLE analysis in a developing country, particularly a fossil-importing country, that analyzes the adoption of e-PUVs with more inclusive points of view of various public transport stakeholders. Additionally, previous studies applied PESTLE analysis using secondary data $[25,29,69,70]$ and interviews with representatives from car companies [24] as well as vehicle drivers and passengers [26]. This study fills these gaps with three proposed contributions. First, we applied PESTLE to analyze the barriers and drivers of a sustainable public transport system in the context of a developing country. We used the case of the Philippines due to the following characteristics: carbon-intensive transport sector that contributes to the majority of air pollution, the country is dependent on imported fossil fuels, electricity mix is dominated by carbon-based sources, high investment cost for cleaner PUVs, and weak governance in implementing policies related to sustainable transportation. Second, we focused on case-specific types of electric vehicles including e-jeepneys and e-trikes, 
which are the most common modes of public transportation in the Philippines. Third, we look at the perspective of different transport stakeholders. These include the main stockholders (passengers, drivers, transport operators), other stakeholders (investors, businesses, gas/electricity distributors, vehicle manufacturers), and transport experts (law, policy, governance, environment, labor, engineering, academia).

\section{Materials and Methods}

\subsection{Initial Interview and Results}

We divided the methodology into two stages: the preliminary interview and the survey. In the first stage, we interviewed ten experts including a policymaker, economist, public official, lawyer, engineer, environmentalist, urban planner, labor group leader, transportation consultant, and university professor. This stage is intended to identify various drivers that affect investment decisions for the adoption of e-PUVs. Given the answers of the experts, we identified the most common factors for each aspect of PESTLE and constructed the survey questionnaire.

\subsection{PESTLE Analysis}

Based on the initial interview with experts, we outline here the factors that affect the adoption of e-PUVs in the case of the Philippines.

Political drivers refer to both local and national government policies as well as the implementation of the policies which affect public transport operations. These include national and local political stability, strict implementation of the PUVMP on eliminating old PUVs operating for more than 15 years, government subsidy on e-PUV investment, implementation of "Tanggal bulok-Tanggal usok" (TBTU) that controls smoke-belching and dilapidated PUV, and the proposed "no garage-no car" policy that prohibits buying new vehicles without enough private parking space or terminals for PUVs.

Economic drivers refer to the factors that affect the economic or financial performance of e-PUVs in terms of demand-supply, prices, as well as the purchasing power of buyers and passengers. The identified economic drivers for the adoption of e-PUVs include the high investment cost for e-PUV, expected decrease in e-PUV price in the future, increasing electricity and gasoline/diesel prices, local manufacturing or importation of e-PUVs, national economic stability, including stability of commodity prices, and increasing base fare for all PUVs.

Social drivers refer to the factors that affect the social environment such as public acceptance, health benefits, or other determinants like socio-cultural trends, demography, and population. In the case of the Philippines' e-PUV adoption, social drivers include the popularity of more sustainable modes of transportation, increasing preference for renewable energy sources, safer and more secure public transportation ride, more comfortable ride with e-PUV, and indirect health benefits of e-PUV from lower to zero GHG and air pollutants.

Technological drivers refer to innovations in technology that affect the operations and favorability of EVs. The technological drivers for e-PUV adoption included in the survey are technological progress on developing more efficient and environment-friendly PUV, expanding automation businesses and EV sales, availability of charging stations, renewable sources of electricity, availability of auto-parts shops for buying EV spare parts, and the availability of mechanic shops and technical expertise of mechanics to repair EVs.

Legal drivers refer to the existing public transportation laws and regulations. In the case of the Philippines, transportation laws include the Clean Air Act, which controls the emissions from all types of vehicles, the PUVMP, which gives incentives for the purchase of EVs for public transportation, the Alternative Fuel Vehicles Incentive Act, which provides incentives for R\&D of e-PUVs, the extended Motor Vehicle Development Program, which provides zero tariffs for e-vehicles, and the most recent Inter-Agency Council for Traffic (iACT) program called "Tanggal Bulok, Tanggal Usok" (remove old vehicles, remove smoke), which aims to remove deteriorated and smoke-belching PUVs. 
Environmental or ecological drivers refer to factors that are determined by the surrounding environment. The identified environmental factors affecting the adoption of e-PUVs include the issues of climate change and global warming, energy transition to net-zero carbon economy, decreasing air and noise pollution from EVs, expanding environmental programs at the national level, and traffic decongestion in urban and rural areas.

\subsection{Respondents, Questionnaire, and Data Collection}

Respondents of the study included various aspects of the public transportation system: commuters, drivers, stakeholders, and experts. The survey collected 1371 responses, however, only 1319 responses were used as some of them were rejected due to incompleteness. The passengers and drivers are those who ride or drive public transport vehicles such as buses, vans, jeepneys, taxis, uber, grab, tricycles, and scooters. Stakeholders include transport operators and businesses affected by PUVMP such as vehicle manufacturers, auto parts sellers, mechanic repair shops, gas stations, and electricity distributors. The transportation experts are the same as those described in the interview stage. The total number of the respondents for each category is summarized in Table 1.

Table 1. Summary of respondents.

\begin{tabular}{cc}
\hline Profile & Number \\
\hline Commuters & 939 \\
Drivers & 465 \\
Stakeholders & 152 \\
Experts & 164 \\
\hline
\end{tabular}

The survey questionnaire is divided into two parts. The first part asked how the identified PESTLE factors can be an opportunity/driver or a risk/barrier in the transition towards the electric public transport system. We added space for each aspect such that the respondents can supplement additional drivers that are not listed on the survey questionnaire. The second part of the survey asked for solutions, other than electric vehicles, as well as to identify government policies that make the public transport system more sustainable. To ensure the reliability of our questionnaires, we conducted a test-retest with 50 respondents at a 15-day interval period. We applied the Chi-square statistic, which is a non-parametric, distribution-free tool designed to analyze group differences among categorical variables. The test result with a $p$-value $<0.05$ indicates that we can reject the null hypothesis and conclude that there is a statistically significant association between the variables.

Data were collected using both an online survey and face-to-face interview between August and December 2019. Since most drivers, operators, and business owner respondents had no access to the online survey, face-to-face interviews were done and the questionnaires were explained using the local language (e.g., Tagalog, Visayan, Ilonggo, Ilocano, Bicolano, English). The survey interviews were administered by the researchers as well as eight research assistants assigned in all geographic regions. To avoid sampling bias, random interviews with different transport stakeholders were done covering all geographic areas in the Philippines: Luzon, Visayas, Mindanao, and Metro Manila. To ensure ethical considerations of research, we informed all respondents about the details of the study. Participation in the study was voluntary and the respondents could withdraw any time without any consequences. We informed the respondents about the academic purpose of the study, guaranteed anonymity of respondents by assigning encrypted codes, and ensured the confidentiality of responses as only the researchers had access to the research data. 


\section{Results}

\subsection{PESTLE Analysis}

Based on our theoretical framework that combines participatory development and good governance, we present the survey results on how various PESTLE factors could be drivers or barriers for the transition to sustainable public transport with the participation of various stakeholders, including commuters, drivers, stakeholders, and experts. The summary of the survey result is presented in Table 2. Except for social and environmental aspects, it can be observed that responses for different factors can be different from various stakeholders. This is due to the differences in interests among different groups. For instance, in Political and Legal aspects, the PUVMP and its implementation are regarded as drivers for PUV passengers and experts as these offer a common good for society. On the contrary, these are barriers for drivers and other stakeholders as the modernization may result in possible losses of jobs and businesses. Meanwhile, in the Economic aspect, a higher base fare for PUVs is a barrier for commuters as this implies additional daily expenses. However, this is an enabler for transport drivers and operators as this implies higher daily earnings and income. In terms of energy prices, higher electricity rates or diesel/petrol prices are barriers for commuters and drivers as these incur additional operations costs and higher fares. On the other hand, fuel distributors and energy generators see these as opportunities for higher income and growth in business. Further, the following are the findings for each PESTLE aspect.

Table 2. Barriers and drivers for the adoption of electric vehicles (EVs) for public transport $(\mathrm{D}=$ driver, $\mathrm{B}=$ barrier).

\begin{tabular}{|c|c|c|c|c|}
\hline PESTLE Factors & Commuters & Drivers & Stakeholders & Experts \\
\hline \multicolumn{5}{|l|}{ Political } \\
\hline Government Subsidy & $\mathrm{D}$ & $\mathrm{D}$ & $\mathrm{D}$ & $\mathrm{D}$ \\
\hline PUVMP implementation & $\mathrm{D}$ & $\mathrm{B}$ & $\mathrm{B}$ & $\mathrm{D}$ \\
\hline Political Stability & $\mathrm{B}$ & $\mathrm{B}$ & $\mathrm{B}$ & $\mathrm{B}$ \\
\hline Disposal of old vehicles & $\mathrm{D}$ & $\mathrm{B}$ & $\mathrm{B}$ & $\mathrm{D}$ \\
\hline No garage-No car policy & $\mathrm{B}$ & $\mathrm{B}$ & $\mathrm{B}$ & $\mathrm{D}$ \\
\hline \multicolumn{5}{|l|}{ Economic } \\
\hline High investment cost & B & B & B & B \\
\hline Decreasing cost of e-PUVs & $\mathrm{D}$ & $\mathrm{D}$ & $\mathrm{D}$ & $\mathrm{D}$ \\
\hline High Electricity Prices & $\mathrm{B}$ & $\mathrm{B}$ & $\mathrm{D}$ & $\mathrm{B}$ \\
\hline High Gasoline/Diesel Prices & B & $\mathrm{B}$ & $\mathrm{D}$ & $\mathrm{D}$ \\
\hline Importation of PUVs & $\mathrm{B}$ & $\mathrm{B}$ & B & $\mathrm{B}$ \\
\hline Local Manufacturing of PUVs & $\mathrm{D}$ & $\mathrm{D}$ & $\mathrm{D}$ & $\mathrm{D}$ \\
\hline Economic stability & $\mathrm{D}$ & $\mathrm{D}$ & $\mathrm{D}$ & $\mathrm{D}$ \\
\hline Higher Base fare & $\mathrm{B}$ & $\mathrm{D}$ & $\mathrm{D}$ & $\mathrm{B}$ \\
\hline \multicolumn{5}{|l|}{ Social } \\
\hline Increasing popularity of e-PUVs & $\mathrm{D}$ & $\mathrm{D}$ & $\mathrm{D}$ & $\mathrm{D}$ \\
\hline Renewable sources of electricity & $\mathrm{D}$ & $\mathrm{D}$ & $\mathrm{D}$ & $\mathrm{D}$ \\
\hline Safety/Security & $\mathrm{D}$ & $\mathrm{D}$ & $\mathrm{D}$ & $\mathrm{D}$ \\
\hline Comfortable ride & $\mathrm{D}$ & $\mathrm{D}$ & $\mathrm{D}$ & $\mathrm{D}$ \\
\hline Indirect health effect & $\mathrm{D}$ & $\mathrm{D}$ & $\mathrm{D}$ & $\mathrm{D}$ \\
\hline Resistance from transport groups & B & $\mathrm{B}$ & B & $\mathrm{B}$ \\
\hline \multicolumn{5}{|l|}{ Technological } \\
\hline Technological progress & $\mathrm{D}$ & $\mathrm{D}$ & $\mathrm{D}$ & $\mathrm{D}$ \\
\hline Increasing automotive business & $\mathrm{D}$ & $\mathrm{D}$ & $\mathrm{D}$ & $\mathrm{D}$ \\
\hline Availability of charging stations & $\mathrm{B}$ & $\mathrm{B}$ & $\mathrm{B}$ & $\mathrm{B}$ \\
\hline Development of renewable energy & $\mathrm{D}$ & $\mathrm{B}$ & $\mathrm{D}$ & $\mathrm{D}$ \\
\hline Availability of auto parts supply & $\mathrm{B}$ & $\mathrm{B}$ & $\mathrm{D}$ & $\mathrm{B}$ \\
\hline Availability of Mechanic/repair shop & $\mathrm{B}$ & $\mathrm{B}$ & $\mathrm{D}$ & $\mathrm{B}$ \\
\hline
\end{tabular}


Table 2. Cont.

\begin{tabular}{ccccc}
\hline PESTLE Factors & Commuters & Drivers & Stakeholders & Experts \\
\hline Legal & & & & \\
\hline Clean air act & $\mathrm{D}$ & $\mathrm{D}$ & $\mathrm{D}$ & $\mathrm{D}$ \\
PUVMP & $\mathrm{D}$ & $\mathrm{B}$ & $\mathrm{B}$ & $\mathrm{D}$ \\
Alternative Fuel Vehicles Act & $\mathrm{D}$ & $\mathrm{B}$ & $\mathrm{D}$ & $\mathrm{D}$ \\
Motor vehicles development Act & $\mathrm{D}$ & $\mathrm{D}$ & $\mathrm{D}$ & $\mathrm{D}$ \\
Tanggal-bulok Tanggal-usok & $\mathrm{D}$ & $\mathrm{B}$ & $\mathrm{D}$ & $\mathrm{D}$ \\
Traffic decongestion/color coding & $\mathrm{D}$ & $\mathrm{D}$ & $\mathrm{D}$ & $\mathrm{D}$ \\
\hline Environmental & & & & \\
\hline Climate change & $\mathrm{D}$ & $\mathrm{D}$ & $\mathrm{D}$ & $\mathrm{D}$ \\
Transition to low-carbon economy & $\mathrm{D}$ & $\mathrm{D}$ & $\mathrm{D}$ & $\mathrm{D}$ \\
Air pollution & $\mathrm{D}$ & $\mathrm{D}$ & $\mathrm{D}$ & $\mathrm{D}$ \\
Noise Pollution & $\mathrm{D}$ & $\mathrm{D}$ & $\mathrm{D}$ & $\mathrm{D}$ \\
Environmental programs & $\mathrm{D}$ & $\mathrm{D}$ & $\mathrm{D}$ & $\mathrm{D}$ \\
Traffic decongestion & $\mathrm{D}$ & $\mathrm{D}$ & $\mathrm{D}$ & $\mathrm{D}$ \\
\hline
\end{tabular}

\subsubsection{Political}

The findings show that strict implementation of PUVMP and TBTU are the strong drivers for investments in e-PUVs. Among the given factors, respondents emphasized the proper disposal of old vehicles, particularly those operating for more than 30 years. They added that the government must give subsidy, not only to purchase e-PUVs but also to scrap old PUVs. Scrapping subsidy gives additional benefit for owners to give up their vehicles and adopt e-PUVs. Respondents also support the implementation of the new transportation policy on purchasing private cars referred to as "No garage, No car". This policy prohibits the buyers from purchasing new vehicles without a private parking space for the vehicle. This policy aims to decongest the cities by having lesser private cars on the road, no cars illegally parked on the streets, and encourage the public to take PUVs. While the demand for PUVs increases, the strict implementation of the PUVMP will push drivers, operators, and investors to adopt e-PUVs. Respondents further suggested other political factors such as a strong position of local government officials on the adoption of e-PUVs in their respective cities, eliminating the bribes for traffic violations, prohibit lobbying of fleet operators to demonopolize the transport system, and eradicating the corruption in the Land Transportation Office (LTO), particularly on vehicle registration and franchising.

\subsubsection{Economic}

The result shows that developing manufacturing facilities within the country and avoid importing e-PUVs from other countries like China are the most influencing economic factors on the adoption of e-PUVs. These facilities will create more jobs, boost the local economy, and may eventually decrease the investment cost for e-PUVs due to the learning curve and price competition among local producers. Another concern for drivers and operators is the high investment cost for e-PUVs. Currently, the government only provides $5 \%$ purchase equity for those who will adopt e-PUVs. Respondents agree with the previous study that this amount is insufficient, especially for e-jeepney which costs around USD 23 thousand to USD 31.7 thousand, and that the government give modest incentives for prospective e-jeepney fleet investors makes no significant impact in the investment decisionmaking process $[6,71]$. Moreover, increasing gasoline and diesel prices shift investment towards e-PUVs. As the country is highly dependent on imported fossil fuels, changes in global market prices of these commodities have a significant impact on the country's economy, particularly on a fossil-dependent sector like transportation. Increasing input fuel prices incurs an additional operating cost for c-PUVs, making it a disadvantage compared with the EVs counterpart. 


\subsubsection{Social}

Respondents agree that e-PUVs offering a more comfortable and safer ride increases its attractiveness over c-PUVs. Consumers, with good knowledge and positive perceptions of automated vehicles on safety, comfort, and purchase price, are most likely to purchase vehicles [72]. Another comfort feature of e-PUVs is the ease of payment through electronic wallets which gives exact payment, no cash, and no need for change. This is in addition to modern features of e-PUVs including air-conditioning and wi-fi connections which give additional convenience to passengers suffering from heavy traffic, heat, and air pollution. Cultural barriers should be added to the list as heritage advocates are concerned about the aesthetic value of jeepneys which have become a symbol of Philippine culture and arts. On the other hand, e-PUVs would be another attraction for local and international tourists as it is a modernized symbol that cannot be found in any other country.

\subsubsection{Technological}

The findings show that technological progress, availability of charging stations, and availability of mechanic shops are the main technological factors for the adoption of e-PUVs. Technological progress, which pertains to the development of the performance, safety, size, and style of EVs, is one of the main drivers for the penetration of EVs in the market [73,74]. Another factor is the access to private charging infrastructure in both private and public places may become a factor influencing people's willingness to purchase EVs [75,76]. Questions raised by the respondents include the capability of the common automotive mechanic in repairing EVs and the availability of repair shops for e-PUVs. To address this issue, the technical knowledge of mechanics all around the country should be upgraded with the help of the country's Technical Education and Skills Development Authority (TESDA). This could also be added as part of the subject in the Technical-Vocational strand of the new K-12 education curriculum. In this case, the local government must plan specific locations where e-PUVs can operate. Strategic locations should include routes with shorter distances with mostly flat roads. Otherwise, e-PUVs should be designed to travel in steep terrains or roads in mountainous provinces.

\subsubsection{Legal}

The result shows that the Clean Air Act, TBTU, and PUVMP are the legal drivers affecting the adoption of e-PUVs. The Clean Air Act is a law that aims to maintain clean air by controlling all private motor vehicles and PUVs to update engines and controls the renewal of vehicle registration. This law is in line with the TBTU, which controls and removes all very old vehicles on the road, those that emit black soot, and PUVs not meeting the National Air Quality standards. Other legal drivers include traffic decongestion, such as the color coding and number coding schemes which aim to curb the high volume of vehicles plying on Metro Manila city roads to manage the peak-hour traffic, the Alternative Fuel Vehicles Incentive Act, which provides incentives to manufacture, sell, and import hybrid vehicles, and which offers tax incentives to individuals and corporations involved in R\&D of e-PUVs, and the extended Motor Vehicle Development Program, which provides zero tariffs for e-vehicle components, parts, and accessories for the assembly of hybrid, electric, flexible fuel, and other alternative fuel vehicles.

\subsubsection{Environmental}

The findings show that the concern for pollution is the main environmental factor for e-PUV adoption. As the PUVs contribute to $94 \%$ of the soot particle mass in major cities, respondents see the adoption of e-PUVs as a long-term and more sustainable solution for addressing air pollution. Another factor is traffic congestion, which is currently one of the major issues in the country. According to the National Economic and Development Authority [77], traffic congestion creates about USD 55.8 million in economic loss each day, which increases to USD 64.39 million per day at the peak of the rainy season. In total, traffic congestion loses the country around $0.8 \%$ of its gross domestic product, accounting 
for USD 18 billion each year. With the introduction of e-PUVs under PUVMP, respondents believed that this will partially solve the problem by replacing the old, polluting, unsafe vehicle fleet, transforming the industry business model in TBTU to one that is free of hazardous and unproductive on-street competition, and creating more systematic and efficient PUV system routes. Other relevant drivers include climate change and energy transition to a low-carbon economy. Recently, the Philippines submitted an intended nationally determined contribution to the 2015 United Nations Climate Change Conference (COP21) which outlined a provisional commitment of 70\% reduction in GHG emissions by 2030 relative to the business-as-usual levels [78]. Along with the changes in the power mix towards more renewables, deployment of end-use conservation measures, and differentiated sector growth, electrification of the transport sector is considered an important low-carbon measure towards achieving the country's GHG emission reduction goals.

\subsection{Solutions to Sustainable Public Transport}

To gain more insights on ways how the country can adopt cleaner and more sustainable modes of public transportation, we asked the respondents for possible solutions and programs that they could propose to the government. Among them are government policies, various modes of sustainable transportation, public infrastructure development, technical skills training for drivers and mechanics, and intensifying the R\&D for EVs. Suggestions on policy recommendations include purchase subsidy, tax discount, removal of dilapidated combustion vehicles, standardization of registration, and controlling the manufacturing/purchasing locally made and imported EVs. Selected responses are as follows:

"The government should increase the subsidy for buying electric vehicles. Public transport should not be privatized."-Transportation Consultant/Analyst

"The government should provide tax incentives for the owner of the electric vehicle." Bus, jeepney, and taxi Commuter

"The government must strictly implement the Clean Air Act particularly with the registration vehicles as well as non-renewal of old and smoke-belching vehicles."Government Official, Policy Maker

"Vehicle replacement every 30 years. If the vehicle is not replaced by then, the cost of tax for renewal should be doubled or tripled."-Bus passenger

"The Tanggal-Bulok Tanggal-Usok program should be strictly implemented to remove very old public vehicles that emit a lot of black smoke."-Autoparts Distributor

"I agree with No Garage, No Car policy as this may limit the number of sales of new cars, reduce the number of cars illegally parked on the roads, and therefore decrease the volume of traffic." -Jeepney Driver

"The government must standardize the emission testing for vehicles and must strictly implement it. For those imported or locally made vehicles, there must be standards to follow such as EURO 4 or 6 engines."-Mechanical Engineer

"Strict implementation of PUV modernization program and Government subsidy for electric vehicles." - Industrial Engineer

Another highlight of the interviews was the modes of transportation raised by several respondents, predominantly on mass transportation and massive infrastructure. This is most likely due to the country's limited railway footprint of $212.4 \mathrm{~km}$ from 4 train lines in Metro Manila [10]. With the construction of several railway projects across the country, including the first subway line in Metro Manila under the "Build, build, build" Program of the Duterte administration [10], respondents also value greener modes of transportation such as walking, bicycling, and using the traditional 2-wheeled carriage drawn by a horse "kalesa". These would only be possible through intensive road widening projects that include lanes for bicycles as well as pavements for pedestrians. Among the responses were: 
"The government should add more lanes for bikes and pedestrians to encourage the commuters to ride bikes or to walk/run/jog for exercise. We cannot do away with these changes, what matters most is how we preserve our environment towards sustainable development."-Urban/City Planner

"Long-term sustainability would require transforming the way we build our cities and integrating cycling, as well as walking, into our transport planning processes." Environmentalist

"The government should provide lanes for bicycles and pavement for people who want to walk."-Urban Planning Professor

"Government should increase investments in mass public transport like the tram, elevated urban electric train, subway, and bullet train, at the same time invest in renewable energy sources."-Bus Commuter

"Before doing the e-PUVs, the government needs to improve quality of the roads and infrastructures, especially on provinces. The e-PUVs cannot cross a river without bridges and that is the problem."-Tricycle Commuter

Although EVs may seem a promising solution towards a zero-emission transport sector, good public information dissemination as a foundation for its adoption has been disregarded. This is where multimedia and social media platforms may play a vital role in information-dissemination and innovation diffusion [79]. The findings from the survey support this claim as the respondents convey the significant role of media in public information on the benefits of EVs and their influence on energy transition and climate change. While the respondents hope that the government will do its part to accelerate the development of localized EV technologies that will eventually induce growth not only in the transport sector but for the whole economy, they also highlighted further improvements of minor areas that were often over-looked, such as the technical skills of the drivers and their knowledge of basic traffic rules and regulations. Selected responses are as follows:

"Information dissemination about the benefits of renewable energy and integration of the concepts of sustainable developments in other allied subject areas which may promote sustainable communities."-Tricycle Commuter

"As a requirement to obtain license and franchise, the government should require the drivers to attend a seminar on road and traffic rules. Also, drivers of old PUVs should be hired to drive the e-PUVs."-Jeepney Commuter

"Develop local-made solar-powered vehicles to boost our car manufacturing industry. Since we are in a tropical country, we receive a huge amount of sunlight and we can use it to power up our transportation modes. This will lead to a lesser carbon footprint by consuming electricity from renewable energy. We could also tie-up with institutions to intensify the said notion for the betterment of the process."-Bus, Jeepney Commuter

\section{Discussion}

\subsection{Barriers to Sustainable Public Transport}

Applying the PESTLE analysis, this study investigated whether each factor is a barrier or a driver for the adoption of e-PUVs. Comparing the PESTLE analysis, results showed that the economic and technological factors were the main barriers to the adoption of e-PUVs. These factors include the high upfront cost to own an EV and competitive prices of diesel over electricity, as well as the availability of charging stations, mechanic/repair shops, and auto-parts supply stores. These results confirm previous studies that the top barriers to the adoption of EVs are the relatively higher cost of ownership compared to internal combustion vehicles, shortage or lack of available charging infrastructures, lack of consumer awareness about EV technology, and poor long-term goal setting on the part of the government [80-82]. The total ownership cost of EVs is relatively higher than combustion vehicles due to high-input material cost, higher operational cost, and insufficient infrastructure resulting in higher pay-back period [80]. In the case of the 
Philippines, the EV market is not yet established, resulting in a higher purchase price. While the government gives a $5 \%$ subsidy for purchasing EVs for public transport, the modest incentive for aspiring EV owners makes no significant impact on their decisionmaking process [71].

In terms of operational cost, the prices of fossil fuels are relatively cheaper compared to electricity [83]. Relative to neighboring countries (e.g., Indonesia, Malaysia, Thailand) with the vertically integrated and highly subsidized power sector, the Philippines' power industry is privatized, regulated by monopolies, has no government subsidy, fully costreflective, and is heavily taxed across the supply chain, resulting in higher electricity prices $[84,85]$. As the country is highly dependent on imported fossil fuels for electricity generation, the price of electricity is expected to increase in the next decades [86,87]. Consequently, given the higher capital cost of EVs, owners and operators will still prefer to own and use combustion vehicles with lower operational costs.

Another key barrier to EV adoption is the availability of adequate charging facilities, close to homes and workplaces [88]. With premature EV technology in the Philippines, the country lacks EV charging facilities available for both PUVs and private vehicles. Also, the availability of EV spare parts and mechanic shops, in case the EV needs to be repaired, increases the skepticism of owners and operators to adopt EVs. At present, the charging stations, along with EVs and hybrid EVs, are procured by the Japanese Government and delivered to the Philippines through the Department of Energy (DOE) for deployment to identified beneficiaries under the terms of grant aid [89]. Aside from the availability, the complexity of planning a charging infrastructure for EVs should be considered. The factors to be considered may include the target group, geographical characteristics of a region, type of charging station, access, payment, pricing modalities, and roaming [90].

As e-PUVs run in various routes in the country, their operations are affected by different distance ranges, terrain features, extreme temperatures, and power shortages [10]. These factors affect not only the transport operations but the operating life and performance of EVs as well. Battery monitoring is therefore crucial for these e-PUVs because the safety, operation, and even the life of the passengers depend on the battery system [91]. This feature is exactly the major function of the battery management system (BMS) - to check and control the state of charge and state of health of battery for safe and reliable operating conditions [91-93]. The BMS protects the battery from overcharging, overuse, and shortcircuiting [94].

\subsection{Drivers to Sustainable Public Transport}

Among the PESTLE factors, we identified that social followed by legal and political drivers enable the adoption of EVs for a sustainable public transport system in the Philippines. The results identified that social acceptance, government laws on the development, purchase, and use of EVs, as well as the implementation of government policies are the top drivers. Public opinion or social acceptance is indispensable to the successful establishment of electric mobility in the automotive market [90]. In the case of the Philippines, PUV drivers and commuters preferred to drive/ride due to its modern features such as air-conditioning, non-contact payment, availability of Wi-Fi and USB port, navigation, and more comfortable ride. This result confirms previous studies that the Philippines, relative to neighboring Asian countries, has the highest public perception with a majority of the Filipinos expressing interest in owning, driving, or riding EVs than combustion vehicles $[10,95]$. This high public acceptance rate implies a positive outlook on the development and penetration of EVs in the public transport system in the next years. On the other hand, the findings showed that the Clean Air Act, disposal of old combustion vehicles, and PUVMP were the legal drivers for the adoption of e-PUVs. However, the respondents reiterated that proper and strict implementation of these laws and other policies are necessary for a successful transition to a more sustainable public transport system in the country. 


\subsection{Implications of the Study}

Electrification of public transport has a direct and indirect relevance to the UN SDGs. Direct transport targets of SDGs include \#3-ensure healthy lives and promote well-being for all at all ages (with road safety), \#7-ensure access to affordable, reliable, sustainable, and modern energy for all (with a higher energy efficiency of EVs), \#9-build resilient infrastructure, promote inclusive and sustainable industrialization, and foster innovation (with sustainable infrastructure such as roads, bridges, railroads), \#11-make cities and human settlements inclusive, safe, resilient, and sustainable (with sustainable modes of public transport), and \#12-ensure sustainable consumption and production patterns (with sustainable sources of energy for transport) (UN SDGs). On the other hand, indirect targets include \#3-ensure healthy lives and promote well-being for all at all ages (with improved air quality), \#11—make cities and human settlements inclusive, safe, resilient, and sustainable (cities with sustainable public transportation), and \#13-take urgent action to combat climate change and its impacts (with reduced GHG emissions from EVs) [96].

To meet the UN SDGs, different countries are shifting to more sustainable transport systems. Achieving a sustainable transport needs a combination of different measures: better-designed cities, non-motorized transport infrastructure, more public transport, and cleaner and more energy-efficient road fleets, including electric vehicles [97]. However, countries are facing various systemic challenges to adopting EVs, such as policy coordination among ministries and key stakeholders, lack of infrastructure and standards, high upfront costs for EVs and new infrastructure, and a general lack of awareness and understanding of the technologies [98]. Planning the transition to a sustainable transport system should be considered holistically. Sustainable development must be participatory as aspirations for real change rarely come from the government but civil society [99].

Based on the theories of participatory development and good governance, this study employed PESTLE analysis to provide a more holistic point of view of transport stakeholders on external factors affecting the adoption of EVs for sustainable public transport. The findings highlighted that the modernization of public transport with PUVMP would most benefit the PUV passengers. Compared with developed countries, passengers in the Philippines, particularly in urban areas, are at risk from riding dilapidated old PUVs due to traffic congestion, air pollution, and possible road accidents. With e-PUVs, the program offers a safer and more comfortable ride. On the other hand, PUVMP causes grave concern and objection among many stakeholders with the possible loss of livelihood of drivers and operators [11]. Other stakeholders are also affected by this transition, particularly the automotive manufacturing industry, gas station owners, and auto supply and repair shops. The sustainable transition is further hampered by active resistance from various transport operations as well as local executives and legislators. Rather than formulating policies that address the interests of the opposing groups, the government should attempt to work with the automotive industry and these transport groups by stimulating the support of small operators and increasing various financial and policy incentives [11,100]. Furthermore, essential key stakeholders including the national and local governments, automobile manufacturers and importers, electricity producers and grid operators, PUV drivers and operators, and various others set common goals and work together to achieve them [100].

\subsection{Policy Recommendations}

Electrification of transport plays a significant role in reducing GHG emissions and improving air quality. To accelerate the transition towards a zero-emission public transport system, the findings recommend the following government policies:

- Boost the investment in renewables to increase the current $21 \%$ of the total energy mix to make more renewable energy available for charging EVs.

- Develop more public infrastructures which include wider roads with bike and pedestrian lanes as well as parking and charging stations for electric vehicles.

- Diversify the transport sector by investing in electric mass transportation such as railways, subways, and water ferries. 
- Improve the government incentives such as purchase subsidy, tax exemptions, and operational support.

- Fund the development of locally made electric vehicles to create a good market, increase the competition, lower the prices, create more jobs, and increase the economic activity.

- Set a long-term goal and strictly implement government policies related to importation, development, purchasing, registration, operation, and disposal of electric vehicles.

- Carry out a massive information campaign geared towards educating the public on the benefits, advantages of electric public transport, and the subsidy program of the government.

\subsection{Limitations and Future Research}

This study has several limitations. First, the survey included 1319 respondents consisting of PUV drivers, commuters, stakeholders, and transport experts. We admit that this number is still not enough to represent all transport stakeholders. Caution must be observed in making generalizations based on the results of this study.

Second, we conducted an initial interview with transport experts from academia, business, policymakers, law, and civic organizations. To avoid conflict of interest and maintain the impartiality of the study, we excluded officials from the Department of Transportation (DoTr). However, this resulted in questions on the relevance of the factors from the sustainable transport planning point of view such as the traffic congestion as a part of the environmental factor and the availability of mechanic/repair shop as a part of the technological factor. One of ten components of the PUVMP is the Route Rationalization based on the data of appropriate mode, quantity, and characteristics of PUVs in each geographical area, which will make the routes served by the most appropriate mode of transport that is responsive to passenger demand [11]. The shift in jeepney operations from the boundary system to more efficient route management will eliminate driver incentives for frequent lane-changing, stopping, and idling, and will address pollution and traffic congestion in major cities in the Philippines [101]. Another component of PUVMP is Industry Consolidation, which aims to consolidate small operators and drivers to form a cooperative or corporation to obtain a franchise. The cooperative, as long as their constitution provides, can engage in other economic activities such as putting up a gasoline station, an auto supply shop, batteries supply shop, and mechanic repair shop [102]. To improve the factors included in the PESTLE analysis and their relevance from the perspective of transport planning, an initial interview with the transport expert group may comprise a representative from DoTr.

Another limitation is the ambiguity of the items in the PESTLE factors. For instance, for the investment cost for EVs, respondents indicated that this is an economic driver. With lower technology costs, operators and transport fleet owners will be encouraged to adopt EVs. On the other hand, the item is also a barrier due to the current state of EVs with a high cost of ownership. Therefore, the interviews and open-space comments from respondents addressed this issue. Future surveys should indicate, for instance, "high investment cost of EVs", to avoid this ambiguity. Furthermore, questions should also elucidate whether the e-PUV targets of 100,000 units/year of e-trikes for 6 years as well as 200,000 units of e-jeepneys were met and how people were reacting with these government targets. So far, no studies have reported nor monitored the developments of the penetration of EVs in the public transport system in line with the PUVMP targets, hence, it is a good consideration for further research.

In this research, we focused our analyses on two types of e-PUVs: e-jeepneys and e-trikes, as these are the most common modes of public transportation in the case country. Future studies may consider other modes of public transportation such as buses, trains, ships, and planes. Other than battery electric vehicles, hydrogen vehicles and hydrogenelectric vehicles may also be considered in line with the government's plan to develop green hydrogen production in the Philippines. 
This qualitative research applied PESTLE analysis to identify the drivers and barriers to the adoption of e-PUVs. While the results provided a good basis for decision-support for the adoption of EVs for public transport, the analysis only looked at the external factors, hence, the results obtained are not complete. Considering the internal factors is equally important in decision-making, particularly for transport operators who need to draw huge investments in obtaining the new technology for this transition. This qualitative approach can be complemented by integrating other quantitative methods such as life cycle analysis, socio-technical whole system analysis, and economic analysis under uncertainties $[6,103,104]$. Despite these limitations, we believe that this study could serve as a good benchmark for further analysis of the adoption of a more sustainable public transport system.

\section{Conclusions}

Electrification of the public transport system is a promising solution to decarbonize the transport sector. Electric vehicles, as a replacement for combustion vehicles, reduce air pollution and dependence on fossil fuels. The adoption of electric vehicles for public transport has been discussed in the literature ranging from economic to technological perspectives. This study contributes to the literature by (1) applying PESTLE analysis to evaluate the adoption of electric vehicles for public transport in the case of the Philippines, a fossil import-dependent developing country, (2) focusing on the case-specific mode of electric public transport, such as electric jeepneys and electric tricycles, and (3) looking at the vantage points of different transport stakeholders including drivers, operators, passengers, experts, and businesses. Using a theoretical framework that combines participatory development and good governance, we unpack the different elements of public transport modernization and their interactions that provided a broader understanding of the complexity of the transition to sustainable transportation. We applied PESTLE analysis to investigate how political, economic, social, technological, environmental, and legal drivers affect the shift in the modes of public transportation from combustion to electric vehicles jeepneys and electric tricycles to support the Philippines' public utility vehicle modernization program.

Results identified economic and technological factors as the main barriers to the adoption of electric public transport. Among these barriers include the high investment cost for electric vehicles, high operational cost with relatively more expensive electricity prices compared to oil, lack of charging infrastructure, driving range and use in different terrains, and the availability of auto parts, stores, and mechanics in case of vehicle repair. On the other hand, the main driver for the adoption of electric vehicles is the significant public acceptance, with the majority of the commuters, drivers, and operators supporting the modernization of the public transport system. This is backed up by policy and legal drivers which include the standardization and modernization of public transport, disposal of old vehicles, and infrastructure development. To make an emission-free public transport system, this study recommends that the government should invest in renewable sources of energy, develop more public infrastructure, diversify the transport sector, fund the development of locally made electric vehicles, and initiate a massive information campaign in educating the public of its advantages.

Author Contributions: Conceptualization, C.S.G., A.A.C. and C.B.A.; methodology, C.B.A.; validation, C.S.G.; formal analysis, A.A.C. and C.B.A.; investigation, C.S.G. and A.A.C.; data curation, C.S.G. and A.A.C.; writing-original draft preparation, C.S.G. and C.B.A.; writing-review and editing, C.S.G. and A.A.C.; visualization, C.B.A.; supervision, C.B.A.; project administration, C.S.G. All authors have read and agreed to the published version of the manuscript.

Funding: This research received no external funding.

Data Availability Statement: The data in this study are available on request from the corresponding author. 
Acknowledgments: The authors acknowledge the support from Utrecht University, Mindoro State College of Agriculture and Technology, and University of Science and Technology of Southern Philippines-Cagayan de Oro Campus. The authors would like to thank our research assistants: Earl John L. Cabigon and Anniefhel C. Amo as well as the anonymous experts and respondents of the study.

Conflicts of Interest: The authors declare no conflict of interest.

\section{References}

1. International Energy Agency. Global EV Outlook. Available online: https://www.iea.org/reports/global-ev-outlook-2020 (accessed on 24 January 2020).

2. Pasdar, A.A.; Mansouri, M. A Better Policy for Electric and Low-Emission Cars Using Systems Thinking. In Proceedings of the 2020 IEEE Conference on Technologies for Sustainability (SusTech), Santa Ana, CA, USA, 23-25 April 2020; pp. 1-6.

3. Gong, S.; Ardeshiri, A.; Rashidi, T.H. Impact of government incentives on the market penetration of electric vehicles in Australia. Transp. Res. Transp. Environ. 2020, 83, 102353. [CrossRef]

4. Azarafshar, R.; Vermeulen, W.N. Electric vehicle incentive policies in Canadian provinces. Energy Econ. 2020, $91,104902$. [CrossRef]

5. Santos, G.; Davies, H. Incentives for quick penetration of electric vehicles in five European countries: Perceptions from experts and stakeholders. Transp. Res. Policy Pract. 2020, 137, 326-342. [CrossRef]

6. Agaton, C.B.; Guno, C.S.; Villanueva, R.O.; Villanueva, R.O. Diesel or Electric Jeepney? A Case Study of Transport Investment in the Philippines Using the Real Options Approach. World Electr. Veh. J. 2019, 10, 51. [CrossRef]

7. Asghar, R.; Rehman, F.; Ullah, Z.; Qamar, A.; Ullah, K.; Iqbal, K.; Aman, A.; Nawaz, A.A. Electric vehicles and key adaptation challenges and prospects in Pakistan: A comprehensive review. J. Clean. Prod. 2021, 278, 123375. [CrossRef]

8. Tabares, E.M.; Toro, C.A.R.; Mercado, J.E.; Londono, D.A.C.; Mejia, S.E.R. Analysis of Electric Vehicle Policies in the Colombian Market: The City of Medellín as a Case Study. In Proceedings of the 2020 Congreso Internacional de Innovación y Tendencias en Ingeniería (CONIITI), Bogota, Colombia, 30 September-2 October 2020; pp. 1-6.

9. Department of Energy. Road Transport Patrol. Available online: https://www.doe.gov.ph/road-transport-patrol-0?ckattempt=1 (accessed on 25 January 2021).

10. Agaton, C.B.; Collera, A.A.; Guno, C.S. Socio-Economic and Environmental Analyses of Sustainable Public Transport in the Philippines. Sustain. J. Rec. 2020, 12, 4720. [CrossRef]

11. Sunio, V.; Gaspay, S.; Guillen, M.D.; Mariano, P.; Mora, R. Analysis of the public transport modernization via system reconfiguration: The ongoing case in the Philippines. Transp. Res. Policy Pract. 2019, 130, 1-19. [CrossRef]

12. Andalecio, A.B.P.; Aquino, K.E.C.; Cruz, C.F.A.; De Guzman, A.; Kiong, N.T.C. Implementation, challenges and stakeholders perception of modernized Jeepneys in Metro Manila. J. Phys. Conf. Ser. 2020, 1529, 32067. [CrossRef]

13. De Rubens, G.Z.; Noel, L.; Kester, J.; Sovacool, B.K. The market case for electric mobility: Investigating electric vehicle business models for mass adoption. Energy 2020, 194, 116841. [CrossRef]

14. Berkeley, N.; Bailey, D.; Jones, A.; Jarvis, D. Assessing the transition towards Battery Electric Vehicles: A Multi-Level Perspective on drivers of, and barriers to, take up. Transp. Res. Policy Pract. 2017, 106, 320-332. [CrossRef]

15. Berkeley, N.; Jarvis, D.; Jones, A. Analysing the take up of battery electric vehicles: An investigation of barriers amongst drivers in the UK. Transp. Res. Transp. Environ. 2018, 63, 466-481. [CrossRef]

16. Hamurcu, M.; Eren, T. Electric Bus Selection with Multicriteria Decision Analysis for Green Transportation. Sustain. J. Rec. 2020, 12, 2777. [CrossRef]

17. Manzolli, J.A.; Trovão, J.P.; Antunes, C.H. Scenario-Based Multi-criteria decision analysis for rapid transit systems implementation in an urban context. eTransportation 2021, 7, 100101. [CrossRef]

18. Elavarasan, R.M.; Afridhis, S.; Vijayaraghavan, R.R.; Subramaniam, U.; Nurunnabi, M. SWOT analysis: A framework for comprehensive evaluation of drivers and barriers for renewable energy development in significant countries. Energy Rep. 2020, 6, 1838-1864. [CrossRef]

19. Kowalska-Pyzalska, A.; Kott, J.; Kott, M. Why Polish market of alternative fuel vehicles (AFVs) is the smallest in Europe? SWOT analysis of opportunities and threats. Renew. Sustain. Energy Rev. 2020, 133, 110076. [CrossRef]

20. Ahmed, R.; Karmaker, A.K. Challenges for Electric Vehicle Adoption in Bangladesh. In Proceedings of the 2019 International Conference on Electrical, Computer and Communication Engineering (ECCE), Cox's Bazar, Bangladesh, 7-9 February 2019; pp. 1-6.

21. Suman, N.H.; Chyon, F.A.; Ahmmed, S. Business strategy in Bangladesh-Electric vehicle SWOT-AHP analysis: Case study. Int. J. Eng. Bus. Manag. 2020, 12, 1847979020941487. [CrossRef]

22. Christodoulou, A.; Cullinane, K. Identifying the Main Opportunities and Challenges from the Implementation of a Port Energy Management System: A SWOT/PESTLE Analysis. Sustain. J. Rec. 2019, 11, 6046. [CrossRef]

23. Månsson, A. Energy security in a decarbonised transport sector: A scenario based analysis of Sweden's transport strategies. Energy Strat. Rev. 2016, 13-14, 236-247. [CrossRef] 
24. Jiang, J.; Blank, A.; Maier, F.; Bharthepudi, A.; Kumar, P. Financial analysis and comparison of compact electric and gasoline cars. In Proceedings of the 2015 Portland International Conference on Management of Engineering and Technology (PICMET), Portland, OR, USA, 2-6 August 2015; pp. 511-518.

25. Hernanz, J.G.; Morales-Alonso, G.; Sánchez, G.F.; González, E.P.; Chaparro, T.S. Electrification of Madrid Fleet Public Transport Company (EMT-Madrid): Strategic Analysis and Implementation. Int. J. Prod. Manag. Eng. 2019, 7, 107-116. [CrossRef]

26. Sobhani, G.; Imtiyaz, N.; Azam, S.; Hossain, M. A framework for analyzing the competitiveness of unconventional modes of transportation in developing cities. Transp. Res. Policy Pract. 2020, 137, 504-518. [CrossRef]

27. Woodruf, J. Reason to Use SWOT \& PESTLE Analysis. Chron. Available online: https://smallbusiness.chron.com/reason-useswot-pestle-analysis-40810.html (accessed on 7 March 2021).

28. Chodakowska, A. The Mobility Revolution in the Automobile Industry. Electric Cars and Battery Management. Bachelor Thesis, Saviona University of Applied Sciences, Kuopio, Finland, 2018.

29. Capuder, T.; Sprčić, D.M.; Zoričić, D.; Pandžić, H. Review of challenges and assessment of electric vehicles integration policy goals: Integrated risk analysis approach. Int. J. Electr. Power Energy Syst. 2020, 119, 105894. [CrossRef]

30. Matthews, T.; Hirve, M.; Pan, Y.; Dang, D.; Rawar, E.; Daim, T.U. Tesla Energy. In Innovation Management in the Intelligent World; Springer International Publishing: Berlin/Heidelberg, Germany, 2020; pp. 233-249.

31. Advantages and Disadvantages of PESTLE Analysis. Latest Quality. Available online: https://www.latestquality.com/ advantages-disadvantages-pestle-analysis/\#: \{\}:text=PESTLE\%20analysis\%20is\%20useful\%20for,main \%20benefits \%20of \% 20 PESTLE\%20analysis (accessed on 7 March 2021).

32. Srivastava, P.R.; Zhang, Z.; Eachempati, P.; Lyu, H. An Intelligent Framework for Analyzing the Feasible Modes of Transportation in Metropolitan Cities: A Hybrid Multicriteria Approach. J. Adv. Transp. 2021, 2021, 1-22. [CrossRef]

33. Glotz-Richter, M.; Koch, H. Electrification of Public Transport in Cities (Horizon 2020 ELIPTIC Project). Transp. Res. Procedia 2016, 14, 2614-2619. [CrossRef]

34. Buzzoni, L.; Pede, G. New prospects for public transport electrification. In Proceedings of the 2012 Electrical Systems for Aircraft, Railway and Ship Propulsion, Bologna, Italy, 16-18 October 2012; pp. 1-5. [CrossRef]

35. Rogge, M.; Wollny, S.; Sauer, D.U. Fast Charging Battery Buses for the Electrification of Urban Public Transport-A Feasibility Study Focusing on Charging Infrastructure and Energy Storage Requirements. Energies 2015, 8, 4587-4606. [CrossRef]

36. Azadeh, A.; Salehi, V.; Kianpour, M. Performance evaluation of rail transportation systems by considering resilience engineering factors: Tehran railway electrification system. Transp. Lett. 2018, 10, 12-25. [CrossRef]

37. Yiangkamolsing, C.; Laoonual, Y.; Channarong, S.; Katikawong, W.; Sasawat, P.; Yaotanee, B. A Development of Electric Tuk Tuk Conversion in Thailand. In Proceedings of the 2019 IEEE Transportation Electrification Conference and Expo, Asia-Pacific (ITEC Asia-Pacific), Seogwipo, Korea, 8-10 May 2019; pp. 1-8.

38. Li, Y.; Chang, Y. Road transport electrification and energy security in the Association of Southeast Asian Nations: Quantitative analysis and policy implications. Energy Policy 2019, 129, 805-815. [CrossRef]

39. Köhler, S.; Norkauer, A.; Schmidt, M.; Loidl, V. Electrified Ultralight Vehicles as a Key Element for Door-to-Door Solutions in Urban Areas. In Innovations for Metropolitan Areas; Springer International Publishing: Berlin/Heidelberg, Germany, 2020; pp. 65-76.

40. Sameeullah, M.; Chandel, S. Design and analysis of solar electric rickshaw: A green transport model. In Proceedings of the 2016 International Conference on Energy Efficient Technologies for Sustainability (ICEETS), Nagercoil, India, 7-8 April 2016; pp. 206-211.

41. Mateo-Babiano, I.; Recio, R.B.; Ashmore, D.P.; Guillen, M.D.; Gaspay, S.M. Formalising the jeepney industry in the Philippines-A confirmatory thematic analysis of key transitionary issues. Res. Transp. Econ. 2020, 83, 100839. [CrossRef]

42. Dominković, D.; Bačeković, I.; Pedersen, A.; Krajačić, G. The future of transportation in sustainable energy systems: Opportunities and barriers in a clean energy transition. Renew. Sustain. Energy Rev. 2018, 82, 1823-1838. [CrossRef]

43. Haddadian, G.; Khodayar, M.E.; Shahidehpour, M. Accelerating the Global Adoption of Electric Vehicles: Barriers and Drivers. Electr. J. 2015, 28, 53-68. [CrossRef]

44. Zhang, R.; Fujimori, S. The role of transport electrification in global climate change mitigation scenarios. Environ. Res. Lett. 2020, 15, 34019. [CrossRef]

45. Shi, S.; Zhang, H.; Yang, W.; Zhang, Q.; Wang, X. A life-cycle assessment of battery electric and internal combustion engine vehicles: A case in Hebei Province, China. J. Clean. Prod. 2019, 228, 606-618. [CrossRef]

46. Simao, J.V.; Cellina, F.; Rudel, R. Critical barriers precluding the electrification of road public transport in Southern Switzerland. In Proceedings of the 2020 Fifteenth International Conference on Ecological Vehicles and Renewable Energies (EVER), Monte-Carlo, Monaco, 10-12 September 2020; pp. 1-9.

47. Xylia, M.; LeDuc, S.; Laurent, A.-B.; Patrizio, P.; Van Der Meer, Y.; Kraxner, F.; Silveira, S. Impact of bus electrification on carbon emissions: The case of Stockholm. J. Clean. Prod. 2019, 209, 74-87. [CrossRef]

48. Bousse, Y.; Corazza, M.V.; Arriaga, D.S.; Sessing, G. Electrification of Public Transport in Europe: Vision and Practice from the ELIPTIC Project. In Proceedings of the 2018 IEEE International Conference on Environment and Electrical Engineering and 2018 IEEE Industrial and Commercial Power Systems Europe (EEEIC / I\&CPS Europe), Palermo, Italy, 12-15 June 2018; pp. 1-6. 
49. Schneider, H. Participatory Governance: The Missing Link for Poverty Reduction; OECD Development Center Policy Brief No. 17; OECD: Paris, France, 1999.

50. Organisation for Economic Co-Operation and Development (OECD). Evaluation of Programs Promoting Participatory Development and Good Governance. Available online: https:/ / www.oecd.org/dac/evaluation/dcdndep/35019452.pdf (accessed on 9 March 2021).

51. Opaluwah, A.O. Participatory Development: A Tool of Pedagogy. Exch. Interdiscip. Res. J. 2016, 4, 120-139. [CrossRef]

52. Global Development Research Center. Participatory Development and Good Governance. Available online: https://www.gdrc. org/u-gov / doc-jica_gg.html?fbclid=IwAR1hm3ENRg8k5sRrDIF-YiaUs1AL0V1IWd0ga9RyzylS7P1gH6NL7zKtb_g (accessed on 8 March 2021).

53. Hewitt, R.J.; De Boer, C.; Flacke, J. Participatory development of digital support tools for local-scale energy transitions: Lessons from two European case studies. Glob. Transit. 2020, 2, 138-149. [CrossRef]

54. Keping, Y. Governance and Good Governance: A New Framework for Political Analysis. Fudan J. Humanit. Soc. Sci. 2018, 11, 1-8. [CrossRef]

55. JICA Research Institute. Participatory Development and Good Governance Report of the Aid Study Committee. Available online: https://www.jica.go.jp/jica-ri/IFIC_and_JBICI-Studies/english/publications/reports/study/topical/part/part_5.html (accessed on 9 March 2021).

56. Le Pira, M.; Ignaccolo, M.; Inturri, G.; Pluchino, A.; Rapisarda, A. Modelling stakeholder participation in transport planning. Case Stud. Transp. Policy 2016, 4, 230-238. [CrossRef]

57. Haial, A.; Berrado, A.; Benabbou, L. Managing Stakeholder Participation in Transport Decision Making: Perspective of Public Pharmaceuticals Supply Chain in Morocco. In Proceedings of the 2020 5th International Conference on Logistics Operations Management (GOL), Rabat, Morocco, 28-30 October 2020; pp. 1-7.

58. Perera, R. The PESTLE Analysis; Nerdynaut: Avissawella, Sri Lanka, 2017.

59. Atighechian, G.; Maleki, M.R.; Aryankhesal, A.; Jahangiri, K. Are Macro and Micro Environment Affecting Management of Fresh Water Resources? A Case from Iran with PESTLE Analysis. Mater. Socio Med. 2016, 28, 307-313. [CrossRef]

60. Sridhar, R.; Sachithanandam, V.; Mageswaran, T.; Purvaja, R.; Ramesh, R.; Vel, A.S.; Thirunavukkarasu, E. A Political, Economic, Social, Technological, Legal and Environmental (PESTLE) approach for assessment of coastal zone management practice in India. Int. Rev. Public Adm. 2016, 21, 216-232. [CrossRef]

61. Dalirazar, S.; Sabzi, Z. Strategic analysis of barriers and solutions to development of sustainable buildings using PESTLE technique. Int. J. Constr. Manag. 2020, 1-30. [CrossRef]

62. Ulubeyli, S.; Kazanci, O. Holistic sustainability assessment of green building industry in Turkey. J. Clean. Prod. 2018, 202, 197-212. [CrossRef]

63. Yudha, S.W.; Tjahjono, B. Stakeholder Mapping and Analysis of the Renewable Energy Industry in Indonesia. Energies 2019, 12, 602. [CrossRef]

64. Islam, F.R.; Mamun, K.A. Possibilities and Challenges of Implementing Renewable Energy in the Light of PESTLE \& SWOT Analyses for Island Countries. In Green Energy and Efficiency; Springer Science and Business Media LLC: Berlin/Heidelberg, Germany, 2017; pp. 1-19.

65. Achinas, S.; Horjus, J.; Achinas, V.; Euverink, G.J.W. A PESTLE Analysis of Biofuels Energy Industry in Europe. Sustain. J. Rec. 2019, 11, 5981. [CrossRef]

66. Rácz, L.; Fozer, D.; Nagy, T.; Tóth, A.J.; Haáz, E.; Tarjani, J.A.; Andre, A.; Selim, A.; Valentinyi, N.; Mika, L.T.; et al. Extensive comparison of biodiesel production alternatives with life cycle, PESTLE and multi-criteria decision analyses. Clean Technol. Environ. Policy 2018, 20, 2013-2024. [CrossRef]

67. Fozer, D.; Sziraky, F.Z.; Racz, L.; Nagy, T.; Tarjani, A.J.; Toth, A.J.; Haaz, E.; Benko, T.; Mizsey, P. Life cycle, PESTLE and Multi-Criteria Decision Analysis of CCS process alternatives. J. Clean. Prod. 2017, 147, 75-85. [CrossRef]

68. Pihkola, H.; Tsupari, E.; Kojo, M.; Kujanpää, L.; Nissilä, M.; Sokka, L.; Behm, K. Integrated Sustainability Assessment of CCS-Identifying Non-technical Barriers and Drivers for CCS Implementation in Finland. Energy Procedia 2017, 114, 7625-7637. [CrossRef]

69. Tan, J.; Chua, W.L.; Chow, C.L.; Chong, M.C.; Chew, B.C. PESTLE Analysis on Toyota Hybrid Vehicles. In Proceedings of the International Conference on Technology Management and Technopreneurship 2012, Melaka, Malaysia, 7-8 February 2012.

70. Sin, C.K.; Ng, W.C.; Tan, L.W.; Ong, J.Q.; Chew, B.C. PESTLE Analysis on Toyota Prius. In Proceedings of the International Conference on Technology Management and Technopreneurship 2012, Melaka, Malaysia, 7-8 February 2012.

71. Bubeck, S.; Tomaschek, J.; Fahl, U. Perspectives of electric mobility: Total cost of ownership of electric vehicles in Germany. Transp. Policy 2016, 50, 63-77. [CrossRef]

72. Hardman, S.; Berliner, R.; Tal, G. Who will be the early adopters of automated vehicles? Insights from a survey of electric vehicle owners in the United States. Transp. Res. Transp. Environ. 2019, 71, 248-264. [CrossRef]

73. Neves, S.A.; Marques, A.C.; Fuinhas, J.A. Technological progress and other factors behind the adoption of electric vehicles: Empirical evidence for EU countries. Res. Transp. Econ. 2019, 74, 28-39. [CrossRef]

74. Rezvani, Z.; Jansson, J.; Bodin, J. Advances in consumer electric vehicle adoption research: A review and research agenda. Transp. Res. Transp. Environ. 2015, 34, 122-136. [CrossRef] 
75. Patt, A.; Aplyn, D.; Weyrich, P.; Van Vliet, O. Availability of private charging infrastructure influences readiness to buy electric cars. Transp. Res. Policy Pr. 2019, 125, 1-7. [CrossRef]

76. Shen, X. With the Right Government Incentives, Electric Vehicle Adoption Could Rise. Chicago Policy Review (Online). Available online: https:/ / search.proquest.com/scholarly-journals/with-right-government-incentives-electric-vehicle/docview/222077 1703 /se-2?accountid=190474 (accessed on 21 January 2020).

77. National Economic Development Agency. Roadmap for Transport Infrastructure Development for Metro Manila and its Surrounding Areas. Technical Report No. 1. Environment and Hazard Risk Reduction Analysis. Available online: http: / /www.neda.gov.ph/wp-content/uploads/2015/03/FR-TR1-ENVI-AND-RISK-12149621.pdf (accessed on 21 January 2020).

78. Andong, R.F.; Sajor, E. Urban sprawl, public transport, and increasing CO2 emissions: The case of Metro Manila, Philippines. Environ. Dev. Sustain. 2015, 19, 99-123. [CrossRef]

79. Yan, J.; Zhou, Y.; Wang, S.; Li, J. To share or not to Share? Credibility and Dissemination of Electric Vehicle-Related Information on WeChat: A Moderated Dual-Process Model. IEEE Access 2019, 7, 46808-46821. [CrossRef]

80. Tarei, P.K.; Chand, P.; Gupta, H. Barriers to the adoption of electric vehicles: Evidence from India. J. Clean. Prod. 2021, 291, 125847. [CrossRef]

81. Adhikari, M.; Ghimire, L.P.; Kim, Y.; Aryal, P.; Khadka, S.B. Identification and Analysis of Barriers against Electric Vehicle Use. Sustain. J. Rec. 2020, 12, 4850. [CrossRef]

82. Noel, L.; de Rubens, G.Z.; Kester, J.; Sovacool, B.K. Understanding the socio-technical nexus of Nordic electric vehicle (EV) barriers: A qualitative discussion of range, price, charging and knowledge. Energy Policy 2020, 138, 111292. [CrossRef]

83. Agaton, C.B. A Real Options Approach to Renewable and Nuclear Energy Investments in the Philippine; Logos Verlag: Berlin, Germany, 2019; Volume 71.

84. Ravago, M.L.V.; Brucal, A.Z.; Roumasset, J.; Punongbayan, J.C. The role of power prices in structural transformation: Evidence from the Philippines. J. Asian Econ. 2019, 61, 20-33. [CrossRef]

85. Agaton, C.B. Real Options Analysis of Renewable Energy Investment Scenarios in the Philippines. Renew. Energy Sustain. Dev. 2017, 3, 284-292. [CrossRef]

86. Guno, C.S.; Agaton, C.B.; Villanueva, R.O.; Villanueva, R.O. Optimal Investment Strategy for Solar PV Integration in Residential Buildings: A Case Study in The Philippines. Int. J. Renew. Energy Dev. 2021, 10, 79-89. [CrossRef]

87. Agaton, C.B. Use coal or invest in renewables: A real options analysis of energy investments in the Philippines. Renew. Wind Water Soil 2018, 5, 1. [CrossRef]

88. Adenaw, L.; Lienkamp, M. Multi-Criteria, Co-Evolutionary Charging Behavior: An Agent-Based Simulation of Urban Electromobility. World Electr. Veh. J. 2021, 12, 18. [CrossRef]

89. Vivar, D.V. Philippines Country Report; Economic Research Institute for ASEAN and East Asia: Jakarta, Indonesia, 2019; pp. 273-296.

90. Burkert, A.; Fechtner, H.; Schmuelling, B. Interdisciplinary Analysis of Social Acceptance Regarding Electric Vehicles with a Focus on Charging Infrastructure and Driving Range in Germany. World Electr. Veh. J. 2021, 12, 25. [CrossRef]

91. Cheng, K.W.E.; Divakar, B.P.; Wu, H.; Ding, K.; Ho, H.F. Battery-Management System (BMS) and SOC Development for Electrical Vehicles. IEEE Trans. Veh. Technol. 2011, 60, 76-88. [CrossRef]

92. Chandran, V.; Patil, C.; Karthick, A.; Ganeshaperumal, D.; Rahim, R.; Ghosh, A. State of Charge Estimation of Lithium-Ion Battery for Electric Vehicles Using Machine Learning Algorithms. World Electr. Veh. J. 2021, 12, 38. [CrossRef]

93. Bhattacharjee, A.; Mohanty, R.; Ghosh, A. Design of an Optimized Thermal Management System for Li-ion Batteries under Different Discharging Conditions. Energies 2020, 13, 5695. [CrossRef]

94. Ghosh, A. Possibilities and Challenges for the Inclusion of the Electric Vehicle (EV) to Reduce the Carbon Footprint in the Transport Sector: A Review. Energies 2020, 13, 2602. [CrossRef]

95. Frost \& Sullivan. The Future of Electric Vehicles in Southeast. Asia: Position Paper. Available online: https://asia.nissannews com/en/releases/release-568d250ed392364df4a81d7c61017eee/images/074b20d9e25174eab8146462b7be1932083d9d3a (accessed on 24 January 2021).

96. United Nations. Analysis of the Transport Relevance of Each of the 17 SDGs. Available online: https: / / sustainabledevelopment. un.org/content/documents/8656Analysis\%20of\%20transport\%20relevance\%20of\%20SDGs.pdf (accessed on 8 March 2021).

97. United Nations Environmental Program. Why Does Electric Mobility Matter? Available online: https://www.unep.org/exploretopics/transport/what-we-do/electric-mobility/why-does-electric-mobility-matter (accessed on 7 March 2021).

98. United Nations Industrial Development Organization. What Next for E-Mobility? Available online: https://www.unido.org/ stories / what-next-e-mobility (accessed on 7 March 2021).

99. Elrahman, O. Governance of environmental health and transportation decisions: The case of New York City. Case Stud. Transp. Policy 2019, 7, 463-469. [CrossRef]

100. Rietmann, N.; Lieven, T. A Comparison of Policy Measures Promoting Electric Vehicles in 20 Countries. In Neo-Liberalism and the Architecture of the Post Professional Era; Springer International Publishing: Berlin/Heidelberg, Germany, 2018; pp. 125-145.

101. Sidel, J.T. Averting "Carmageddon" through reform? An eco-systemic analysis of traffic congestion and transportation policy gridlock in Metro Manila. Crit. Asian Stud. 2020, 52, 378-402. [CrossRef]

102. Agoot, L. PUVMP to Professionalize PH Transport System. Philippine New Agency. Available online: https://www.pna.gov.ph/ articles/1076510 (accessed on 8 March 2021). 
103. Sufyan, M.; Rahim, N.; Muhammad, M.; Tan, C.; Raihan, S.; Bakar, A. Charge coordination and battery lifecycle analysis of electric vehicles with V2G implementation. Electr. Power Syst. Res. 2020, 184, 106307. [CrossRef]

104. Geels, F.W. Low-carbon transition via system reconfiguration? A socio-technical whole system analysis of passenger mobility in Great Britain (1990-2016). Energy Res. Soc. Sci. 2018, 46, 86-102. [CrossRef] 